\title{
Usuários de Cocaína-Crack e Recepção de uma Campanha Televisiva Antidrogas
}

\author{
Moises Romanini 1,* \& Adriane Roso ${ }^{2}$ \\ ${ }^{1}$ Universidade de Santa Cruz do Sul, Santa Cruz do Sul, RS, Brasil \\ ${ }^{2}$ Universidade Federal de Santa Maria, Santa Maria, RS, Brasil
}

\begin{abstract}
RESUMO - O objetivo deste artigo é discutir como a recepção e a apropriação das formas simbólicas interferem no cotidiano das pessoas. Pretende-se mostrar algumas das representações sociais que usuários de cocaína-crack têm em relação às formas simbólicas presentes em uma campanha televisiva antidrogas. O campo de pesquisa foi em um Centro de Atenção Psicossocial - Álcool e Drogas (CAPS AD) localizado em uma cidade do interior do Brasil. Para colher informações, foram utilizadas diferentes estratégias: observação participante, diário de campo e grupos focais. Os resultados sugerem que o conteúdo da mídia modifica e é modificado pelo self do receptor e que a mídia de massa tem colaborado com a criação e manutenção de relações de dominação de diferentes ordens.
\end{abstract}

PALAVRAS-CHAVE: psicologia social, representações sociais, meios de comunicação, recepção, cocaína-crack

\section{Crack-Cocaine Users and Reception of an Anti-drug Television Campaign}

\begin{abstract}
The aim of this paper is to discuss how the reception and appropriation of symbolic forms interfere in daily life. We intend to show some of the social representations that crack-cocaine users have in relation to the symbolic forms presented on an anti-drug television campaign. The fieldwork was a Psychosocial Care Center - Alcohol and Drugs (CAPS AD) located in a countryside city in Brazil. To gather information, we used different strategies: participant observation, field diary and focus groups. The results suggest that the content of the media modifies and is modified by the self of the receptor and that the mass media have contributed to the creation and maintenance of relations of dominance of different types. KEYWORDS: social psychology, social representations, media, reception, crack-cocaine
\end{abstract}

O uso do crack entrou em pauta nas discussões de saúde e segurança pública, principalmente nos meios de comunicação. $\mathrm{O}$ uso inadequado de substâncias psicoativas tem sido apresentado como uma grave ameaça à saúde de inúmeros brasileiros e relacionado à elevação dos índices de violência e criminalidade em nossa sociedade (Brasil, 2005; Romani, 2003; Vedovatto, 2010), o que justificaria a adoção de medidas como a da internação compulsória (Cunda \& Silva, 2014). Além disso, constata-se, tanto na mídia escrita (Brasil, 2005; Hartman \& Gollub, 1999; Reinarman \& Levine, 1997; Rodrigues, Conceição, \& Iunes, 2015; Romanini \& Roso, 2012; Roso et al., 2013; Wurdig \& Motta, 2014; Zanotto \& Assis, 2017) quanto na mídia televisiva (Macedo, Roso, \& Lara, 2015; Roso, Romanini, Macedo, \& Angonese, 2012; Romanini \& Roso, 2013), a utilização de estratégias ideológicas nas formas simbólicas veiculadas sobre a denominada "epidemia do crack", construindo no senso comum um perfil do usuário de crack permeado por preconceitos e estigmas.

Entende-se, dessa forma, que é urgente e necessária a disseminação de debates mais aprofundados sobre o "fenômeno das drogas", para que, por meio de uma postura crítica, seja possível desnaturalizar e desmitificar verdades produzidas pelas políticas da "Guerra às Drogas". Declarada pelo governo de Richard Nixon (Estados Unidos), em 1972, a "Guerra às Drogas" tornou-se a tônica na abordagem internacional da questão das substâncias psicoativas ilícitas (Rodrigues, 2003). Por isso, não apenas a análise da recepção é fundamental neste estudo, mas também a preocupação em entender como os usuários de crack percebem essas

\footnotetext{
*E-mail: moisesromanini@yahoo.com.br
} 
propagandas a partir de uma proposta de rodas de conversa, isto é, evidenciar os saberes (representações sociais) dos próprios usuários sobre o tema.

Além disso, este estudo parte do pressuposto de que as representações são sempre sociais. A representação social, enquanto um conhecimento construtivo e de caráter social que se origina nas conversações cotidianas, é uma elaboração de um objeto social (no caso, as drogas) pela comunidade, com o objetivo de conduzir-se e comunicarse em relação aos temas e problemas vividos. Para a Teoria das Representações Sociais, representar significa construir uma realidade sobre o que está em volta para entender e agir no social, constituindo-se como um saber socialmente elaborado e partilhado (Moscovici, 2000/2010; Jovchelovitch, 2007/2008).

É a partir da constatação de que os saberes se transformam ao serem apropriados por diferentes grupos e em diferentes contextos sociais, que Moscovici (1961/2012, 2000/2010) entende as Representações Sociais como uma forma de conhecimento do senso comum e socialmente partilhado. No bojo desse conceito há a pressuposição fundante da teoria, ou seja, a ideia de um conhecimento construído por sujeitos ativos em íntima relação com objetos culturalmente construídos, o que revela tanto as marcas dos sujeitos quanto dos objetos, ambos inscritos social e historicamente. $\mathrm{O}$ conceito de Representações Sociais faz emergir um duplo cruzamento em que, por um lado estão o individual e o social, e por outro o material e ideal (Jodelet, 1989/2005, 2011; Jovchelovitch, 2007/2008, 2011).

Este artigo origina-se da dissertação de mestrado intitulada Rodas de Conversa sobre a (além da) Campanha "Crack nem pensar": a saga do "super-homem moderno" em tempos de crack, defendida junto ao Programa de Pós-Graduação em Psicologia da Universidade Federal de Santa Maria ${ }^{1}$. Neste artigo, há o objetivo de discutir como a recepção e apropriação dos "produtos midiáticos" interferem no cotidiano das pessoas. Pretende-se mostrar algumas das representações sociais circulantes no discurso de pessoas que fazem uso de crack em relação à mídia de massa, notadamente, às formas simbólicas veiculadas na televisão, através dos discursos extraídos das transcrições dos grupos, que foram realizados em um Centro de Atenção Psicossocial - Álcool e outras Drogas (CAPS AD). Ainda, buscamos discutir quatro afirmações importantes sobre as mídias de massa: (a) elas constroem a realidade; (b) não só dizem o que existe (e o que não existe), mas atribuem uma conotação valorativa, de que algo é bom e verdadeiro (ou o contrário); (c) propõem uma agenda de discussão; (d) existe um novo personagem dentro de casa - a televisão (Guareschi, 2009; Guareschi \& Biz, 2005; Guareschi, Romanzini, \& Grassi, 2008).

A Hermenêutica de Profundidade (Thompson, 2007) sustentou teórica e metodologicamente esta pesquisa. Sendo assim, foram utilizadas como estratégias a observação participante, o diário de campo e as rodas de conversa. Após a descrição do método utilizado na pesquisa, será apresentada a análise sociodiscursiva, iniciando com duas cenas extraídas do diário de campo. $\mathrm{Na}$ análise, haverá a apresentação de alguns discursos extraídos dos grupos à luz das quatro afirmações sobre as mídias de massa apresentadas no objetivo (Guareschi, 2009). Por fim, serão retomadas as noções de recepção e apropriação, sugerindo ao final do artigo duas novas afirmações sobre a mídia, a partir da análise empreendida neste artigo.

\section{MÉTODO}

O local escolhido para a realização da pesquisa foi um CAPS AD, em virtude da sua especificidade: o serviço foi criado em uma cidade do interior do estado do Rio Grande do Sul no ano de 2009 com intuito de acolher a demanda crescente por tratamento a pessoas que fazem uso de crack. Os participantes da pesquisa (denominados doravante de interlocutores) foram usuários do referido serviço, com idade superior ou inferior a 18 anos, inseridos em um plano terapêutico.

Para colher informações, utilizaram-se diferentes estratégias, como a observação participante (Angrosino, 2009) nas reuniões de equipe e em outras atividades do serviço, registradas em diário de campo (Azevedo \& Carvalho, 2009; MacRae, 2004), e grupos focais (Barbour 2009; Roso, 1997), aqui denominados Rodas de Conversa, já que esta é uma expressão mais familiar aos usuários do que grupo focal, o que chamaria a atenção dos usuários à participação.

Após um período de inserção de um dos pesquisadores no local, usuários do serviço foram convidados a participar das rodas de conversa em caráter voluntário. Foram realizadas três rodas de conversa durante o primeiro semestre de 2011: a primeira foi composta por sete interlocutores, a segunda por três e a terceira por seis, finalizando com um total de 16 interlocutores ( 2 do sexo feminino e 14 do sexo masculino). Como forma de estimular o debate, foram exibidas duas vezes, nas rodas de conversa, as propagandas da campanha "Crack, nem pensar", veiculadas pelo Grupo Rede Brasil Sul (Grupo RBS, 2009).

Os interlocutores têm idades que variam de 13 a 29 anos. Se for considerado que alguns deles fazem uso há algum tempo (um deles diz consumir crack há quase 10 anos), pode-se pensar que a média de idade do início de uso deve ser bem inferior à média de idade atual dos interlocutores $(22,75$ anos). Conforme as informações contidas nos prontuários,

1 A pesquisa foi aprovada pelo Comitê de Ética em Pesquisa da Universidade Federal de Santa Maria (CAEE $n^{\circ}$ 0006.0.243.000-11) e segue as exigências e procedimentos das Resoluções 196/1996 e 466/2012 do Conselho Nacional de Saúde que regulamentam a pesquisa envolvendo seres humanos. 
apenas um dos 16 interlocutores pode ser considerado de classe média-alta. A maior parte deles vive em situação de pobreza, e alguns dependem do albergue municipal para ter um local para dormir e se alimentar.

A convite dos pesquisadores, dois profissionais do serviço participaram das rodas, um como comediador e outro como observador, de forma voluntária. O convite foi feito à equipe, que ficou responsável por definir quem seriam os profissionais que participariam dos grupos. Deste modo, a realização desta pesquisa não se constituiu em uma simples coleta de dados no local, mas com uma incorporação dos métodos na realidade cotidiana do serviço.
Com base na Hermenêutica de Profundidade (Thompson, 2007), realizou-se uma análise sócio-histórica/discursiva com o objetivo de reconstruir as condições sociais e históricas de produção, circulação e recepção das formas simbólicas. A análise discursiva tem como finalidade básica analisar a organização interna das formas simbólicas, com suas características estruturais, seus padrões e relações (Thompson, 2007). Como existem várias maneiras de conduzir a análise discursiva, foi adotada a análise temática. E, com base nos pressupostos da Psicologia Social Crítica e em autores que estudam a questão das drogas sob um viés crítico, buscou-se interpretar os discursos dos interlocutores.

\section{RESULTADOS E DISCUSSÃO}

A análise sociodiscursiva iniciará por meio da narração de duas cenas, extraídas do Diário de Campo:

\section{$1^{\text {a }}$ Cena}

Hoje o assunto no CAPS foi a morte de um jovem que frequentava o serviço. Tive pouco contato com ele, mas lembro quando ele disse na quinta-feira que não voltaria mais ao CAPS. E não voltou. A equipe estava providenciando sua internação em uma fazenda terapêutica (...). Ele foi baleado por uma policial ao tentar roubar uma escola na madrugada do domingo. Fiquei um pouco chocado ao receber a noticia, mas logo os usuários queriam conversar sobre o assunto. Quando eu estava no pátio com eles, um usuário leu a notícia que foi publicada hoje em um jornal que circula na cidade. Após a leitura, eles discutiram se o rapaz "estava no inferno". Um respondeu: "Ele já vivia no inferno quando estava vivo”. Outro disse: "Claro que está no inferno... ele roubava de pessoas inocentes, usava crack, aloprava por aí...". Após um tempo de discussão, um dos guris disse que não concordava com a opinião dos demais e que encerrassem o assunto, pois estavam falando de crenças religiosas (Notas do Diário de Campo).

\section{$2^{\text {a Cena }}$}

Com um deles [interlocutores das rodas de conversa] houve uma confusão. Eu ainda não havia chegado no CAPS. Esse usuário veio acompanhado da mãe. Essa mãe chegou muito alterada no serviço, acusando a equipe de ter dado o número de telefone da família para um repórter da RBS. Os profissionais da equipe não entendiam o que ela estava falando. Ela disse que está se formando em um curso superior e que iria colocar o CAPS e o "repórter" na justiça (...). Quando ela falou em Campanha da $R B S$, a profissional que a atendia entendeu que a situação se tratava de um mal-entendido e que a mulher estava se referindo à minha pesquisa. No caso, o "repórter" era eu. Desfeito o mal-entendido, essa mãe ficou mais calma, mas mesmo assim solicitou que eu ligasse novamente para confirmar a explicação. Quando cheguei ao CAPS me contaram a situação ocorrida e me disseram que, apesar do rapaz ter demonstrado interesse em participar do grupo, a mãe quis ir embora e levou o filho junto com ela (Notas do Diário de Campo).

De maneiras distintas, as duas cenas narradas mostram a potência da mídia em nossos cotidianos. A primeira refere-se à midiatização da morte de um usuário do serviço, baleado pelas costas quando tentava fugir de um roubo malsucedido. A matéria veicula que a policial militar atirou em "legítima defesa”. O jornal, entregue todas as manhãs no CAPS, passou de mão em mão quando a notícia se espalhou. Todos queriam ler a reportagem que mostrava o "fim previsível" de um usuário de crack que "aloprava por aí" (sic). A discussão sobre o possível "paradeiro" do jovem - o inferno - faz com que se remeta à representação do uso/usuário de drogas como pecado/ pecador (Mota, 2009), cujo "destino final" só pode ser o inferno. Ninguém cogita a possibilidade do "paraíso".

Essa representação, cuja antinomia fundamental é o bem e o mal, lembra, também, a discussão feita por Moscovici (2011) sobre o sagrado e o profano. Nessa cena, pode-se pensar nessa distinção a partir de duas vias. A primeira traz a noção de que o objeto (do furto) é sagrado, o que, por sua vez, se liga a ideia do consumo e ao capital, isto é, ao dinheiro. $\mathrm{O}$ ato profano, dessa forma, é o ato de furtar e atacar não uma pessoa em si, mas um bem ou uma instituição (por exemplo, quando um "bandido" mata um policial, não foi "apenas" uma pessoa atacada, mas, sobretudo, a instituição da polícia, a guardiã da ordem). O bem (o capital, o material, mercadoria), entendido como inviolável e intocável, entretanto, é o que ele toca no ato do furto. E se um "bandido" mata um "bandido"? Ele é "absolvido" pelo senso comum. "Era bandido mesmo!". Porém, se o "bandido" mata um homem "não bandido", todos ficam horrorizados. Então, é o bem que uma pessoa possui/ representa que está na esfera do "sagrado" e não a pessoa em si.

Em uma última instância, o que está em jogo, nessa situação, é o "valor" da vida de cada um: alguns "valem menos", pois estão excluídos do sistema capitalista; outros "valem mais", pois representam bens (o dinheiro e o consumo) e instituições (a polícia, por exemplo). O que parece definir a diferença entre o profano e o sagrado, portanto, não é mais "Deus" ou a "Religião", que diferencia as coisas entre religiosas e não religiosas, mas sim os valores do mercado e do consumo. Há um abismo entre o profano e o sagrado - o paraíso fica muito longe do inferno, o céu da terra. A "proibição de contato" (Moscovici, 2011) foi 
violada nessa história do homicídio veiculada na mídia local: o profano tocou o sagrado, e por isso o jovem pagou com a própria vida (“que já não valia muito!").

A segunda via para pensar a antinomia bem/ mal compreende o sagrado e o profano como temas que podem ou não ser debatidos entre os usuários do serviço. Não há maiores problemas em falar sobre a reportagem veiculada, sobre o uso e sobre os roubos, porém não é permitido conversar sobre "crenças religiosas" e é proibido o "contato" com esse tema. "Cada um tem sua crença e isso não se discute", argumentam os usuários do serviço. Pode-se ver que a própria mídia, de uma maneira geral, procede da mesma forma em relação ao tema drogas. Parece paradoxal, e o é, na verdade, mas o tema das drogas, que é largamente veiculado, tem seus "pontos cegos", que são "proibidos" de entrar nas pautas de discussão.

Por exemplo, veicular a ideia de que famílias desestruturadas levam ao uso de drogas e que esse uso, consequentemente, conduz a práticas criminosas, é corrente, comum e profano (Romanini \& Roso, 2012). Por outro lado, discutir os ideais que se tem de família e problematizar a relação de causalidade estabelecida entre uso de drogas e criminalidade, não. Como foi o próprio discurso científico que produziu as verdades sobre família e sobre os índices de criminalidade associado às drogas, não deve-se questionálos, em tese, pois são verdades "sagradas". Por mais que a Igreja não seja mais considerada o aparelho ideológico hegemônico nos tempos modernos e que, portanto, não "regula" mais a produção de conhecimentos, embora os discursos religiosos pautem em grande medida os debates sobre políticas de drogas no Brasil, há o pensamento de que as religiões continuam a produzir, por meio da dicotomia entre o sagrado e o profano, formas de pensar sobre alguns temas, mesmo que isso seja disfarçado nos discursos científicos, que se dizem laicos.

A segunda cena do diário de campo mostra a outra face da midiação da cultura moderna (Thompson, 2007). A revolta da mãe em relação a uma possível invasão ao sagrado seio de sua família traz à tona uma importante discussão: o paradoxo da família moderna, que é cada vez mais privada e cada vez mais pública (Singly, 2007). Sustenta-se a noção de família como um espaço privado através, por exemplo, da responsabilização atribuída a ela pela dissolução dos costumes e do uso de drogas. Por meio dessa ideia é que é concedido à família um lugar fechado em si mesma, de forma a parecer estar isolada do resto (ou seja, do público). Ao mesmo tempo, ela se torna cada vez mais pública, por meio das intervenções crescentes do Estado (Singly, 2007) e também do papel exercido pela mídia, isto é, tornar público o privado e denunciar famílias que não zelam pela educação de seus filhos.
Essa situação gerou um mal-estar não apenas na mãe desse jovem, mas também trouxe para este estudo algumas reflexões, das quais destacamos duas neste momento. A primeira é a de que o repórter representou uma ameaça à sua família. Isso pode estar servindo como um indício de que algumas famílias possam receber as formas simbólicas veiculadas pela mídia como uma agressão, parecendo que pensaram algo como o colocado no trecho a seguir: "Estão nos culpando pelo nosso fracasso como pais!". Percebese, assim, que essa mãe sentiu-se agredida e violada ao imaginar que a equipe do CAPS tinha dado seu número de telefone ao repórter. Além disso, também permanece o seguinte questionamento: se essa mãe não tivesse uma formação em curso superior, teria ela se posicionado ou teria ela se submetido ao interesse do repórter" sem hesitar? Não há como responder a esse questionamento, mas a Psicologia Social Crítica deve gerar pontos de interrogação.

A segunda reflexão diz respeito à nossa inserção no serviço. Questionamo-nos se também não havíamos, em alguma medida, agido agressivamente, já que essa foi a reação da mãe. Para a maioria das pessoas, ligar para a casa da família, convidar para participar de um grupo cujo objetivo é debater a campanha "Crack nem pensar", apresentar-se como psicólogo e mestrando em psicologia não se configurou como problema. Pelo contrário, a maioria concordou prontamente em participar dos grupos, alguns com bastante entusiasmo. Entretanto, para essa família foi um problema. Essa situação pode ainda ser mais bem analisada, mas por enquanto serviu para refletir sobre o papel dos pesquisadores e o quanto essas intervenções podem ser consideradas invasivas pelos outros.

Ao narrar essas cenas presenciadas no CAPS e registradas no diário de campo, buscamos discutir como a recepção e apropriação dos "produtos midiáticos" interferem no cotidiano das pessoas. Essa análise serviu não apenas para mostrar, por meio das falas extraídas das transcrições dos grupos, algumas das representações que os nossos interlocutores têm em relação à mídia de massa, mas propiciou que pudéssemos discutir quatro afirmações importantes sobre as mídias de massa elencadas por Guareschi (2009). Primeiramente, há a ideia de que a comunicação, atualmente, constrói a realidade; em segundo lugar, de que a mídia não só diz o que existe (e o que não existe), mas também atribui uma conotação valorativa, de que algo é bom e verdadeiro (ou o contrário); em terceiro, há a ideia de que a mídia propõe uma agenda de discussão; por último, de que existe um novo personagem dentro de casa: a televisão. Essas quatro afirmações serão desenvolvidas a seguir. 


\section{(I) A COMUNICAÇÃO, HOJE, CONSTRÓI A REALIDADE}

Até hoje, uma das concepções mais aceitas sobre a televisão a reduz a uma transportadora de conteúdos, isto é, a uma passagem entre um emissor e um receptor. $O$ maior problema dessa concepção, como pondera Bucci (2004a), é que ela ajuda a obscurecer a função fundante dos meios de comunicação, sobretudo dos meios eletrônicos, que é a de construir e conformar o espaço público ou de ser a ágora da modernidade (Guareschi, 2009). A televisão, nesse sentido, não mostra lugares e não traz lugares de longe para perto, mas é, na verdade, um lugar em si. Da mesma forma, ela não supera abismos de tempo com suas transmissões na velocidade da luz, mas encerra outro tempo (Bucci, 2004a).

Realidade é o que existe, o que tem valor, traz as respostas, o que legitima e dá densidade significativa ao nosso cotidiano (Guareschi, 2009, p. 83), isto é, algo passa a existir ou deixa de existir, caso seja ou não midiatizado. Essa afirmação é expressa numa das primeiras falas de um dos grupos: " $E u$ vi, mas eles falam agora só em crack, crack, crack..." (I-J)². O crack e sua dependência, para muitos, senão para a maioria das pessoas, começa a existir como um fenômeno do campo social a partir do momento em que passou a ser repetidamente midiatizado. Outro interlocutor ainda afirma:

Que tem muita gente que conhece o crack assim por propaganda e coisa, mas não sabe o que realmente acontece com o usuário. A propaganda, ela não diz em si, né? Ah, tá ali, dá medo, dá isso e aquilo. Mas não mostra quando a pessoa fica desesperada, quando a pessoa fica entorpecida, né? Quando a pessoa é realmente alterada. Isso ai a propaganda não mostra. Essa é a realidade que eu tô tentando chegar. [Breve silêncio] Isso ai é uma coisa que eu já passei, que eu não pretendo passar de novo. É um troço muito difícil. (I-E)

Pode-se pensar algumas falas em outros termos: "muita gente que conhece o crack assim por propaganda", isto é, as pessoas ficam sabendo sobre o crack via mídia, mas a mídia gera uma informação que não condiz com a percepção de vivência do usuário, ou seja, "não sabe o que realmente acontece com o usuário". A propaganda busca instalar o medo (“A propaganda (...) dá medo, dá isso e aquilo") no receptor, ao invés de criar uma possibilidade de entendimento do receptor sobre o usuário, que é a pessoa que "fica desesperada, quando a pessoa fica entorpecida, né? Quando a pessoa é realmente alterada". Ainda, apesar de o usuário demonstrar um esforço para sair da dependência ("uma coisa que eu já passei, que eu não pretendo passar de novo. É um troço muito dificil"), a propaganda não faz menção a isso. Pode-se refletir, a partir disso, que o importante mesmo para a campanha é focar em quem ainda não usou (e que, portanto, tem salvação!). O usuário, aquele

2 A letra "I" significa interlocutor; seguida sempre da primeira letra do nome fictício da pessoa autora da fala. Mantivemos as falas no original, ou seja, sem correções gramáticas/ortográficas. que já virou um zumbi, é produzido num lugar extremamente estigmatizado. $\mathrm{O}$ discurso preventivo, no tom proposto nessa campanha, mais do que prever uma saída para o uso de crack, participa ativamente na construção de uma visão estereotipada e preconceituosa, dificultando ainda mais as vidas daqueles que sofrem com o uso da droga.

O desejo do interlocutor, que fica explícito em suas falas, é o de que as propagandas mostrem a sua realidade, ou melhor, a realidade vista pelos seus olhos e não pelos olhos de quem nunca usou crack, como apontou uma interlocutora ao afirmar que "o que não é verdade é o que mostraram a pessoa ali quase morrendo e com sangue, e daquele jeito ali". A mesma interlocutora ainda sugere que "é muito melhor mostrar as cenas reais, das pessoas fumando, como fica de verdade, ou mostrar o cérebro de uma pessoa, os neurônios de uma pessoa, o pulmão de uma pessoa, do que mostrar aquilo ali" (I-L).

Outra implicação que se encontra nessa afirmação, por meio das falas dos interlocutores, é que a mídia cria a realidade de duas maneiras: a primeira, que é o sentido corrente dessa afirmação, é que a mídia define o que existe, quando midiatiza algum fenômeno, como é o caso do exemplo supracitado do problema do crack. O segundo sentido, atribuído pelos interlocutores, é que a mídia também cria a realidade ao deturpá-la: "eles fantasiaram muito"(I$\mathrm{AN})$; "acho que $50 \%$ é verdade, mas $50 \%$ eles estão omitindo" (I-R); "por isso que eu digo, eles distorceram um pouco a realidade. Porque a realidade do usuário é bem diferente" (I-AN). Ou seja, ao criar a realidade, há também a (re) criação, e também representações sociais.

$\mathrm{Na}$ opinião deles, as propagandas deveriam apresentar "cenas reais", assim como alguns programas televisivos têm feito, pois "uma reportagem mostrando a realidade é muito mais eficaz que uma propaganda que não é verdadeira, que além de tudo mostra coisas que não é verdade, né?" (I-L). Outra sugestão foi a de mostrar depoimentos de usuários e ex-usuários e também de explicar os sintomas que levam ao uso. No final do primeiro grupo, os interlocutores encerraram o debate afirmando "vamos fazer uma nova propaganda".

Questionamo-nos, entretanto, como e a serviço de que a mídia mostraria essa "realidade". Esse questionamento é fundamental, pois como já assinalamos anteriormente, tanto a mídia escrita quanto a mídia televisiva tem utilizado estratégias ideológicas quando escolhem qual realidade querem transmitir aos leitores/ telespectadores, criando e sustentando relações de dominação, ao reforçar estereótipos atribuídos aos usuários, como os de delinquente ou de doente crônico e incurável. Ao fazer isso, a mídia acaba estreitando a visão sobre um fenômeno muito complexo e reforçando certas representações negativas sobre as pessoas que fazem uso de crack. 
Os interlocutores desse debate falam de um lugar de saber em relação a essa droga. Como eles mesmos afirmaram, todos chegaram "ao fundo do poço" (sic) e conhecem a realidade do uso e tráfico do crack na cidade. Além disso, o espaço dialógico das Rodas de Conversa potencializou considerações críticas a respeito da campanha, sem desconsiderar a relevância disso para a sociedade.

Outro ponto que merece a atenção, nesse debate sobre a "criação de realidade" é a seguinte importante constatação de um interlocutor: "O pessoal bota aquela propaganda que é a mesma de sempre que essa aí..." (I-A), complementada por outro participante: "Só que nenhuma mostra o que é, só o que não é, entendeu?" (I-B). Isso lembra também outra campanha antidrogas: "Drogas, nem morto!". Essa campanha, de abrangência nacional, foi responsável pela veiculação de inúmeras propagandas ainda na década de 1990. Em uma das propagandas, o foco do combate era a maconha. Nela, a maconha é apresentada como a responsável pelas repetidas reprovações na escola de um garoto, fisicamente bem maior que os demais colegas. A propaganda parece pregar uma lição de moral que consiste, resumidamente, em: se você quer ser alguém na vida, não use maconha. Ao final da propaganda, aparecia na tela o slogan "Drogas, nem morto".

A campanha debatida em nossas rodas de conversa, denominada "Crack, nem pensar" , começa a ter suas formas simbólicas veiculadas em 2009, praticamente 10 anos após a veiculação da campanha citada anteriormente e seis anos após a implantação da Política de Atenção Integral aos Usuários de Álcool e outras Drogas. O que a atual campanha inovou ou avançou em relação à campanha da década de 1990? O novo nesta mais atual é o foco na droga crack, e não mais na maconha. Substituiu-se a expressão "nem morto" por "nem pensar". A estrutura discursiva dos slogans é a mesma: Crack (Drogas), Nem pensar (Nem morto)! Isto é, quem não pensa obviamente está morto, e quem usa drogas não pensa. Logo, quem usa drogas está ou em breve estará morto. A lógica é a mesma após 10 anos, como se a política de atenção integral não existisse.

Além de dizer o que existe ou criar a realidade, como procuramos mostrar, a mídia atribui uma conotação valorativa aos fenômenos, afirmando que algo é bom e verdadeiro ou ruim e falso. É o que discutiremos a seguir.

\section{(2) A MÍDIA NÃO SÓ DIZ O QUE EXISTE (E O QUE NÃO EXISTE), MAS ATRIBUI UMA CONOTAÇÃO VALORATIVA, DE QUE ALGO É BOM EVERDADEIRO (OU O CONTRÁRIO)}

Em relação ao uso/ usuário de crack, a campanha, ao atribuir-lhes uma conotação negativa, gera "mais preconceito" e mostra que "ninguém liga pra como tu se sente" (I-E). A atribuição de valores negativos e legitimados como verdades absolutas é sentida por um dos interlocutores por meio da discriminação que sofre cotidianamente:

Eu acho que é um certo tipo de preconceito que tem contra o usuário, que mostra uma realidade muito forçada. (...) $O$ pessoal que vê isso aí, que passou aí, é muita TV, o pessoal assiste muita TV. Pessoal que passa pelo usuário e (...) enxerga daquele jeito... (...) que esse aí não tem mais jeito, esse ai tá morrendo... esse aí vai me roubar... (I-J)

O interlocutor faz uma crítica ao fato de as pessoas assistirem muito televisão e de construírem suas representações a partir das formas simbólicas veiculadas na mídia. A valoração da mídia não se sintoniza com a representação da realidade para o usuário. A consequência disso é simplesmente o afastamento das pessoas dos usuários: o olhar midiático exclui e educa a excluir, ao separar o eu (telespectador) do outro (usuário de crack). A própria mídia é o divisor de águas que situa o usuário para além das margens.

Isso remete ao debate realizado nas rodas de conversa em relação à finalidade ou aos objetivos das propagandas. Pareceu ser consenso que a campanha foi criada para "causar impacto" na sociedade e para chamar a atenção das pessoas para esse grave problema social. A campanha, segundo as discussões, tem a função de "alertar a criança desde pequena, porque depois de adulto isso ai não funciona muito" (I-J) e "está incentivando um pouco os jovens para não... O que é que vai acontecer se eles forem por esse caminho, né?" (I-E). Entretanto, alguns interlocutores afirmam que, para alcançar o objetivo da prevenção, a intenção da campanha é "assustar a pessoa pra ela não querer fumar" (I-L), fazendo do crack um "bicho de sete cabeças" (sic). Essa intenção é

3 No dia 27 de maio de 2009, na sede do Grupo RBS (Rede Brasil Sul) em Porto Alegre, o programa Painel RBS foi apresentado como um evento que fazia parte das ações de lançamento da campanha "Crack, Nem Pensar". A referida campanha foi apresentada pelo presidente do Grupo RBS, Nelson Sirotsky, como uma forma de "enfrentar a epidemia do crack" (Grupo RBS, 2009). Inicialmente, a campanha "Crack, Nem Pensar" foi conhecida pelo grande público com a veiculação da propaganda institucional televisiva intitulada com o mesmo nome da campanha. Além da propaganda, outras ações foram desenvolvidas pelo Grupo RBS: reportagens e matérias veiculadas em jornais, televisão e portais da internet; confecção de camisetas com o logo da campanha (muitas pessoas famosas foram fotografadas usando essas camisetas, como sinal de apoio à campanha); confecção de adesivos e "adesivagem" em diversas cidades dos Estados do Rio Grande do Sul e de Santa Catarina; entre outras. Em 2010 foi lançada a segunda fase da campanha, também no Programa Painel RBS (Grupo RBS, 2010). Nessa oportunidade, além de apresentar a segunda propaganda televisiva, o Grupo RBS apresentou à sociedade 20 Projetos Sociais (13 no Estado do Rio Grande do Sul e 7 no Estado de Santa Catarina) vinculados à Campanha "Crack, Nem Pensar", buscando a mobilização das comunidades para contribuir de forma concreta com projetos voltados à prevenção ao uso do crack. 
considerada errada por alguns, pois pode estar gerando "mais preconceitos" (sic) em relação ao usuário.

A finalidade de propagandas como essas pode ser pensada em termos de visadas, e subentende que o objetivo da comunicação é fazer com que o outro seja incorporado à sua própria intencionalidade. Sob esse aspecto, Charaudeau (2009) compreende quatro tipos de visadas, que se julgou terem sido incorporadas no discurso dos interlocutores: a prescritiva (as propagandas "assustam" a pessoa para ela "não querer fumar"); a informativa (as propagandas servem para "alertar" as pessoas sobre os perigos do crack); a incitativa (as pessoas que assistem as propagandas acreditam que "tudo é verdade", mas "isso é pra enganar o povo", já que mostra uma parte da "realidade"); e a visada do pathós (os telespectadores ficam "assustados", sentem "medo" dos usuários).
Portanto, parece que a campanha é bem-sucedida em suas visadas. Afinal, "olhar daquele jeito" para o usuário como quem "tá morrendo", que "não tem mais jeito" e que "vai me roubar", na verdade, mostra que as pessoas e a mídia "não enxergam o usuário, né" (I-V). Não enxergam, pois conhecem o "problema do crack" por meio das formas simbólicas veiculadas pela televisão e "quem tá de fora vê de um jeito bem diferente" (I-D).

Ao criar a realidade e a atribuir uma conotação valorativa, os meios de comunicação colocam uma pauta de discussão, propõem uma agenda de discussão na sociedade e constroem representações sociais. Quando a "epidemia do crack" passa a ser veiculada através por esses meios, torna-se um ponto importante nas agendas das políticas públicas.

\section{(3) A MÍDIA PROPÕE UMA AGENDA DE DISCUSSÃO}

Muito do que se fala e se discute no cotidiano das pessoas é colocado em pauta pela mídia - por exemplo, a "epidemia do crack", fenômeno até pouco tempo desconhecido que virou tema de debates na população. Um interlocutor fala desta pauta de discussão que é gerada dentro de sua casa, quando a família assiste algum programa de televisão que trata do tema drogas: "Bah. Eu tive que trocar de canal, porque começou a me dar dor de barriga, o troço, cara, eu tava com a minha família em volta, eles nem viram que eu troquei de canal porque dai já começa..." (I-D).

Para esse interlocutor, o tema "crack" é tabu dentro de casa. Ele troca de canal antes que alguém da família perceba o que o programa está abordando. Caso não consiga fazê-lo, o tema se torna pauta de discussão na família. Percebe-se o mesmo na narração da primeira cena no início de nossa análise, quando os usuários do CAPS conversaram sobre a matéria que informava sobre o assassinato ocorrido no último final de semana.

Esse fato ilustra a televisão como um novo espaço público e uma esfera pública expandida. A partir da década de 1960, no Brasil, a televisão tornou-se o suporte dos discursos que identificam o Brasil para o Brasil. A televisão confirma o seu lugar por meio de uma função do olhar, como uma típica esfera pública: "que nos olha, que nos interpela, que nos designa e nos localiza antes de que para ele nós olhemos" (Bucci, 2004a, p. 33). No caso específico da Campanha "Crack, nem pensar", a televisão, enquanto espaço público, "invade" a esfera privada das famílias, pautando o que deve ser discutido. A campanha atinge os lares por meio das duas propagandas geralmente veiculadas nos horários nobres da televisão. As propagandas pautam e são pautadas pelo problema do crack.

Pode-se pensar, assim, que além de ser ou ter um discurso propagandista, as propagandas da referida campanha também contém em si um discurso informativo. Há o discurso propagandista, com a função de persuadir o alvo ("não use crack!"), e o informativo, para transmitir um saber (“o crack causa as piores consequências: dor, prostituição, roubos, assassinatos..."). No discurso propagandista, o status de verdade é da ordem do que há de ser - se usar crack, você ficará semelhante às "pessoas" que mostramos -, enquanto no informativo o status de verdade é da ordem do que já foi (Charaudeau, 2009) - essas consequências são vividas por quem já usou o crack, os especialistas confirmam tal realidade.

E quem cria a pauta? Ou melhor, quem estava envolvido nessa tarefa de persuadir e transmitir um saber à sociedade nessa campanha? A identidade dos parceiros engajados no processo de troca é definida pelas respostas às perguntas: "quem troca com quem?" ou "quem fala a quem?" (Charaudeau, 2009). Nessa condição de enunciação, detectam-se dois aspectos que definem a identidade: os atores envolvidos na construção da campanha e o público-alvo.

Os atores envolvidos na construção da campanha apontados pelos interlocutores são: "o Governo"; " $a$ RBS", inclusive os diretores; "psicólogo"; "terapeuta", "esse tipo de gente que estuda e que quer se especializar em dependência química"; e também "tem o dedinho da OMS". Quanto à participação de usuários na construção da campanha, os grupos apresentam opiniões distintas. O primeiro grupo acredita que houve a participação de um "usuário lunático" e de "cabecinha fraca", pois as propagandas não retratam a realidade. Para o segundo grupo, "devia ter um pouquinho mais da mão de quem tá dentro do mundo" (G2/59. I-J). Já o terceiro grupo tendeu mais para a opinião de que houve a participação de usuários na construção da campanha, como afirmou um dos interlocutores: "quem não usa não sabe como funciona o troço sem se informar com alguém que faz. Quando chega na faculdade se tu... quem é que vai te ensiná o negócio, é o professor, porque ele sabe como que funciona o negócio" (G3/203.I-D).

É importante enfatizar que os atores a os quais a mídia "concede a palavra, prioritariamente não são sempre 
aqueles que estão implicados de modo direto nos fatos, mas aqueles eleitos, especialistas ou cidadãos suscetíveis de ter certa visibilidade social" (Charaudeau, 2009, p. 192). Os eleitos são aqueles que representam a instituição política e, consequentemente, a retórica que utilizam constitui um jargão característico dos políticos. Charaudeau (2009) ainda alerta para o fato de que, quando os especialistas são solicitados a se pronunciar, "sabem que devem falar de uma determinada maneira e, ao mesmo tempo, exibir-se como um 'bom especialista"' (p. 194). Além do mais, as mídias não convocam um especialista qualquer. Dessa maneira, ao colocar a pauta, a mídia já sabe qual conotação valorativa irá atribuir ao fenômeno em questão.

Mas o que a mídia pautou com essa campanha? Essa pergunta faz remeter a uma das condições do ato comunicativo pensadas por Charaudeau (2009): o propósito. O propósito é a condição que nos mostra que todo ato comunicativo é construído em torno de um domínio de saber e é definido a partir da resposta à pergunta: "Do que se trata?" (Charaudeau, 2009). Nas rodas de conversa, buscou-se debater sobre o tema e o foco das propagandas. Vários pontos foram citados: ela fala do usuário; faz uma crítica ao usuário; mostra as consequências do uso da droga; visa à conscientização em relação ao uso de drogas; e aborda a "drogadição", de um modo geral. Parece que neste ponto há uma linha de raciocínio, mesmo que com algumas contradições: na construção de uma campanha que fala dos usuários de crack, destinada predominantemente a pessoas que nunca fizeram uso da droga, há pouca (ou nenhuma) participação dos próprios usuários. Nesse sentido, as rodas de conversa mostraram-se como um espaço efetivo de comunicação, no qual essas pessoas tiveram sua voz e seu saber reconhecidos.

\section{(4) EXISTE UM NOVO PERSONAGEM DENTRO DE CASA - A TELEVISÃO}

Um personagem pode ser qualquer ser ou objeto de uma história. É possível que seja um ser fictício, um humano, um animal ou qualquer outra coisa que o autor inventar. Um personagem pode ter um nome ou não. Neste caso, seu nome é televisão. A palavra personagem deriva do grego persona, que significa o orifício, no local da boca, nas máscaras de teatro por onde se escutava a voz dos atores. Trata-se, sobretudo, de um personagem que muito fala e pouco (ou nada) escuta, e que pelos orifícios de suas caixas de som emite aquilo que deseja transmitir.

Ao mesmo tempo em que os interlocutores acham que a televisão tem a função de retratar a realidade e de colaborar na sua transformação, como, por exemplo, "ajudar a combater o crack", acreditam que "a televisão não tá fazendo nada" (I-E) e o que ela quer é "dar cagaço no cara" (I-E). Retratar a realidade e combater o crack é função da televisão enquanto um personagem presente que interage com o telespectador. A interação tanto existe que os interlocutores dizem ficar curiosos com o que a televisão está "falando" e "de repente é só de falar, que na primeira vez já vicia, ver se é mentira, vou experimentar... Sempre tem gente que pensa desse jeito, né?" (I-E).

A televisão, portanto, é um organismo: "vive" como um organismo (Bucci, 2004b). Além de ser socialmente encarregada de registrar os acontecimentos imediatos e de promover o entretenimento, na tela da TV, a história é processada e reprocessada: "o slogan da CNN costumava ser uma pergunta: 'Onde é que você vai estar da próxima vez que a História acontecer?'. Resposta 'correta': diante da TV. É na TV que a História acontece. É também na TV que ela se reproduz" (Bucci, 2004b, p. 207).

Mas o personagem televisão não se caracteriza somente pela voz e, sim, quase que fundamentalmente pela imagem, que exerce grande influência na maneira como esse personagem se estabelece em nossas casas. A imagem televisual pode ter três funções (Charaudeau, 2009). A função de designação busca mostrar o mundo em sua realidade perceptiva como um "estar-aí". Essa função evidencia efeitos de autenticidade. Esses efeitos não foram percebidos com nossos interlocutores, e, ao contrário, o efeito das imagens foi o de uma "não autenticidade". Para a maioria dos participantes, não há uma identificação com as "pessoas", "ensanguentadas", que "parecem estar com tuberculose", ou seja, não ocorre esse efeito de autenticidade.

A função de figuração busca reconstituir o mundo como ele "foi", tornando-o possivelmente verdadeiro. Em relação a essa função, pôde-se constatar o efeito de verossimilhança pretendido por ela, como foi o caso do interlocutor que achou a imagem do "senhor preocupado" semelhante à imagem do seu pai, no dia em que teve um "surto mesmo". A função de visualização, por fim, consiste em representar coisas do mundo "não visíveis a olho nu" (como representações gráficas, imagens virtuais, etc.). Essa função coloca em cena efeitos de descoberta de verdade, o que não foi percebido na fala dos interlocutores, que consideraram as imagens um "negócio hollywoodiano" demasiadamente dramatizado e desprovido de "verdade".

Portanto, essas afirmações são, ao mesmo tempo, premissas que orientam nossas discussões e preocupações que motivaram a pesquisar as formas como uma mídia de massa tem abordado o tema drogas. Além de serem premissas e preocupações, tais afirmações foram ilustradas no discurso dos próprios interlocutores. As considerações tecidas nos grupos mostra também como a mídia pode influenciar o processo de formação do self - concebido como um projeto simbólico construído ativamente pelas pessoas (Thompson, 2008) - e no papel da televisão como um personagem, algo que pode ser constatado no seguinte discurso: 
O crack tomou conta. O crack tomou conta, como é que vô te dizê? Tu fuma maconha, tu convive com as pessoa tranquilo, claro, o cara pode notar que tu tá meio aéreo, tá com uma cara de bobalhão, mas tudo bem, ele tá ali no meio das pessoas. Tu cheira cocaina, tudo bem, tu tá no meio das pessoas, tu tá convivendo com as pessoas, entendeu? Tu tá numa festa, na balada. Mas tu fuma pedra cara, tu se entoca, tu se entoca, porque eu não sei se é pelo efeito ou pelo efeito que a mídia fez em cima da droga, que é tão errado e tão prejudicial, que tu se esconde num quarto, se esconde num mato, sabe... [grifo nosso] (G3/217. I-D).

Esta frase evidencia o que Thompson (2008) denominou de "quase-interação" mediada. A palavra "quase" funciona nessa definição como um adjetivo, já que ela adjetiva o tipo de interação, isto é, uma quase-interação ou uma interação "pela metade". Não há a total constituição de uma interação, pois envolve um tipo de relação cuja forma de intimidade é essencialmente não recíproca. A televisão fala, é escutada, há o recebimento dos conteúdos que ela veicula, mas ela não escuta de volta e nem vê o telespectador. Mesmo não sendo uma intimidade recíproca, a "quase-interação" mediada produz efeitos no processo de formação do self.

O desenvolvimento dos meios de comunicação de massa tornou esse processo cada vez mais mediado pelos aparatos institucionais das mídias, enriquecendo e acentuando a organização reflexiva do self (Thompson, 2008). Essa organização reflexiva do self, que produz profundos impactos no processo de autoformação, é destacada no trecho grifado anteriormente, no qual o interlocutor, numa posição crítica, pondera sobre a possibilidade do isolamento do usuário ser um efeito da "demonização" da droga, midiatizada principalmente pela televisão. Não que as consequências negativas do uso do crack experimentadas diretamente pelo usuário não influenciem nesse processo, mas aqui o papel da mídia é colocado em cena. O possível aumento do preconceito em virtude da propaganda, como já citado neste artigo, também pode ser considerado um exemplo de como o processo reflexivo de formação do self pode ser influenciado pela mídia.

Contudo, ao mesmo tempo em que as formas simbólicas veiculadas pela mídia atuam no processo de autoformação das pessoas, essas mesmas pessoas interpretam-nas conforme suas pressuposições e expectativas que constituem seu self, o que pode se remeter à noção de recepção como um processo ativo e criativo (Thompson, 2008) e ao conceito de representações sociais como dinâmico e processual (Jodelet, 2005, 1998; Jovchelovitch, 2007/2008; Moscovici, 1961/2012). Nesse sentido, ao interpretar as formas simbólicas, as pessoas incorporam-nas na compreensão que têm de si mesmas e dos outros, utilizando essas formas simbólicas como instrumentos de reflexão e autorreflexão. Esse processo de adaptar as mensagens à própria vida $\mathrm{e}$ aos contextos e circunstâncias vividas é denominado por Thompson (2008) de "apropriação". Portanto, a recepção, a apropriação e a construção de representações sociais são processos interdependentes, como se pôde observar nas concepções que os interlocutores têm de mídia.

\section{CONSIDERAÇÕES FINAIS}

A partir dessa análise, percebe-se que os receptores não são passivos: a recepção de formas simbólicas é sempre uma ação complexa, altamente qualificada e da ordem do singular. A recepção e a apropriação, entendidas como o movimento de "tornar próprio" algo que é novo, são concebidas como processos ativos e potencialmente críticos e devem ser interpretados dentro de um contexto sócio-histórico.

Essa noção de recepção mostra que, mesmo que os indivíduos tenham pouco ou quase nenhum controle sobre os conteúdos das formas simbólicas que os são oferecidas, eles podem trabalhar e reelaborar de maneiras singulares os conteúdos veiculados pelos produtores e construir (novas) representações. Nesse sentido, a recepção sempre envolve a (re) construção de representações sociais. Ela é sempre uma atividade situada (diz de algum lugar, uma referência), rotineira, uma realização especializada que requer habilidades adquiridas ou construídas pelas pessoas e, também, um processo sempre interpretativo, isso é, hermenêutico.

A tradição hermenêutica chama a atenção para um aspecto relevante da interpretação: ao interpretar as formas simbólicas, as pessoas as incorporam na própria compreensão que têm de si mesmos, dos outros e do mundo, via (auto) reflexão, pois na medida que refletem, adaptam as formas simbólicas à própria vida, aos contextos e às circunstâncias vividas. Essa apropriação, sempre em mutação, produz o entendimento sobre o mundo e os modos de agir de cada um, colocando as representações sociais sobre os fenômenos em constante movimento e tensão.

Considerando os processos de recepção, interpretação e apropriação das formas simbólicas aqui analisadas, poderia ser sugerido um complemento às quatro afirmações sobre a mídia discutidas neste artigo: todo conteúdo veiculado pela mídia modifica e é modificado pelo self daqueles que recebem e se apropriam dele, visto que a recepção e a apropriação são sempre processos ativos. Existe uma implicação importante nessa afirmação. Alguns poderiam argumentar que não se faz necessário um controle social daquilo que é veiculado na mídia, uma vez que as pessoas recebem as mensagens de formas distintas e têm a liberdade individual de "trocar de canal", como fez um dos interlocutores quando o assunto na televisão era o crack.

No entanto, é preciso lembrar que a mídia eletrônica está prevista na Constituição Brasileira como um "serviço público", com uma concessão por um determinado período 
de tempo e, portanto, não pode, direta ou indiretamente, ser objeto de monopólio ou oligopólio (Brasil, 1988, Art. 220, Cap. V, $\S 5^{\circ}$ ). A produção e a programação das emissoras de televisão devem dar preferência a finalidades educativas, artísticas, culturais e informativas, além de respeitar os valores éticos e sociais da pessoa e da família (Brasil, 1988, Art. 221). Será que as redes-monopólios (ainda que inconstitucionais) têm conseguido seguir esses princípios?

Sabe-se que por lei, os canais televisivos têm plena liberdade de veicular informação jornalística, desde que observado o disposto no art. $5^{\circ}$, IV, V, X, XIII e XIV (Brasil, 1988). Os discursos trazidos neste artigo dizem sobre a necessidade de olhar com mais cuidado para o que está sendo veiculado/ criado sobre as pessoas que fazem uso de crack. Há que ser salientado que o desenvolvimento dos meios de comunicação nas sociedades modernas tornou possível a veiculação maciça de fenômenos ideológicos, transformando-os em fenômenos de massa. Desse modo, pode-se reafirmar que a mídia televisiva, em geral, tem colaborado com a criação e manutenção de relações de dominação de diferentes ordens, omitindo-se de suas tarefas fundamentais previstas na Constituição Federal, de informar, fornecer entretenimento e educar criticamente os cidadãos. Prova disso são as recentes matérias veiculadas na televisão, mostrando usuários de crack acorrentados em suas casas, vagando pelas "cracolândias" como "zumbis", sujando as ruas das cidades e ameaçando os transeuntes. Tais cenas reforçam os dois lugares destinados aos usuários de crack: o de doente crônico e incurável, cuja única intervenção possível é a internação compulsória; e o lugar do criminoso, cujo destino deve ser a prisão. $\mathrm{O}$ atual desinvestimento nas políticas de saúde mental, na Rede de Atenção Psicossocial e os retrocessos em relação às Políticas sobre Drogas no Brasil indicam uma urgente necessidade de se repensar as formas de falar sobre drogas e de cuidar daqueles que sofrem com o uso de substâncias.

\section{REFERÊNCIAS}

Angrosino, M. (2009). Etnografia e observação participante (Coleção Pesquisa Qualitativa, U. Flick, Coord., J. Fonseca, Trad.). Porto Alegre: Artmed.

Azevedo, B. M. S., \& Carvalho, S. R. (2009). O Diário de Campo como ferramenta e dispositivo para o ensino, a gestão e a pesquisa. In S. R. Carvalho, S. Ferigato, M. E. Barros (Eds.), Conexões saúde coletiva e politicas de subjetividade. (pp. 204-219). São Paulo: Ed. Hucitec.

Barbour, R. (2009). Grupos focais. (Coleção Pesquisa Qualitativa, U. Flick, Coord., M. F. Duarte, Trad.). Porto Alegre: Artmed.

Brasil. (1988). Constituição da República Federativa do Brasil. Brasília, DF: Senado Federal.

Brasil. (2005). Mídia e drogas: O perfil do uso e do usuário na imprensa brasileira. Brasília: Agência de Notícias dos Direitos da Infância, Ministério da Saúde.

Bucci, E. (2004a). A crítica de televisão. In E. Bucci \& M. R. Kehl (Eds.), Videologias - Ensaios sobre televisão (Coleção Estado de Sítio, pp.27-42). São Paulo: Boitempo.

Bucci, E. (2004b). A história na era de sua reprodutibilidade técnica. In E. Bucci \& M. R. Kehl (Eds.), Videologias - Ensaios sobre televisão (Coleção Estado de Sítio, pp. 191-219). São Paulo: Boitempo.

Charaudeau, P. (2009). Discurso das Midias (A. S. M. Corrêa, Trad.). São Paulo: Contexto.

Cunda, M. F., \& Silva, R. A. N. (2014). O crack em um cenário empedrado: Articulações entre os discursos jurídico, médico e midiático. Psicologia \& Sociedade, 26(n.spe.), 245-255.

Grupo RBS. (2009). Painel RBS. Retrieved from http://www. cracknempensar.com.br/

Grupo RBS. (2010). Painel RBS. Retrieved from http://www. cracknempensar.com.br/

Guareschi, P. A. (2009). Psicologia Social Crítica como prática de libertação (4a. ed. rev. ampl.). Porto Alegre: EDIPUCRS.

Guareschi, P. A., \& Biz, O. (2005). Mídia e democracia (5a. ed.). Porto Alegre: P.G/O.B.

Guareschi, P. A., Romanzini, L. P., \& Grassi, L. B. (2008). A "mercadoria" informação: um estudo sobre comerciais de TV e rádio. Paidéia, 18(41), 567-580. Retrieved from http://www. scielo.br/pdf/paideia/v18n41/v18n41a12.pdf

Hartman, D. M., \& Gollub, A. (1999). The social construction of the crack epidemic in the print media. Journal of Psychoactive Drugs, 31(4), 423-433.
Jodelet, D. (2005). Loucuras e representações sociais. (L. Magalhães, Trad.; Coleção Psicologia Social). Petrópolis, RJ: Vozes. (Trabalho original publicado em 1989)

Jodelet, D. (1998). A alteridade como produto e processo psicossocial (pp. 47-68). In A. Arruda (Ed.), Representando a Alteridade. (Coleção Psicologia Social, pp. 47-68). Petrópolis, RJ: Vozes.

Jodelet, D. (2011). A fecundidade múltipla da obra "A Psicanálise, sua imagem e seu público". In A. M. de O. Almeida, M. de F. de S. Santos, \& Z. A. Trindade (Eds.), Teoria das representações sociais: 50 anos (pp. 199-224). Brasília: Technopolitik.

Jovchelovitch, S. (2008). Os contextos do saber-Representações, comunidade e cultura (P. Guareschi, Trad.; Coleção Psicologia Social). Petrópolis, RJ: Vozes. (Trabalho original publicado em 2007)

Jovchelovitch, S. (2011). Representações sociais e polifasia cognitiva: Notas sobre a pluralidade e sabedoria da razão em Psicanálise, sua Imagem e seu Público. In A. M. de O. Almeida, M. de F. de S. Santos, \& Z. A. Trindade. (Eds.). Teoria das representações sociais: 50 anos (pp. 159-178). Brasília: Technopolitik.

Macedo, F. dos S., Roso, A., \& Lara, M. P. de. (2015). Mulheres, saúde e uso de crack: A reprodução do novo racismo na/pela mídia televisiva. Saúde e Sociedade, 24(4), 1285-1298.

MacRae, E. (2004). Abordagens qualitativas na compreensão do uso de psicoativos. In L. A. Tavares, A. R. B. Almeida, E. MacRae \& O. S. Ferreira (Eds.), Drogas: Tempos, lugares e olhares sobre seu consumo. Salvador: EDUFBA, CEETAD/UFBA. Retrieved from: http://www.neip.info/downloads/t_edw9.pdf Moscovici, S. (2012). A Psicanálise, sua imagem e seu público. (Coleção Psicologia Social; S. Fuhrmann, Trad.). Petrópolis: Vozes. (Trabalho original publicado em 1961)

Moscovici, S. (2010). Representações Sociais - Investigações em psicologia social. (P. Guareschi, Trad.; $7^{\mathrm{a}}$ ed.; Coleção Psicologia Social). Petrópolis, RJ: Vozes. (Trabalho original publicado em 2000)

Moscovici, S. (2011). A invenção da sociedade - Sociologia e Psicologia (M. Ferreira, Trad.). Petrópolis, RJ: Vozes.

Mota, L. (2009). Dependência química e representações sociais: Pecado, crime ou doença?. Curitiba: Juruá.

Reinarman, C., \& Levine, H. G. (1997). The crack attack - Politics and Media in the Crack Scare. In C. Reinerman, \& H. G. Levine 
(Eds.), Crack in America: Demon drugs and social justice (pp. 18-51). Berkeley: University of California Press.

Rodrigues, D. R. S. R., Conceição, M. I. G., \& Iunes, A. L. S. (2015). Representações sociais do crack na mídia. Psicologia: Teoria e Pesquisa, 31(1), 115-123.

Rodrigues, T. (2003). Política de drogas e a lógica dos danos. Revista Verve, 3. Retrieved from http://www.neip.info/ downloads/t_tia3.pdf

Romani, O. (2003). Informação sobre drogas: ações, valores e orientações. In M. Baptista, M. S. Cruz \& R. Matias (Eds.). Drogas e Pós-Modernidade-Faces de um tema proscrito (v.2, pp. 33-42). Rio de Janeiro: EdUERJ.

Romanini, M., \& Roso, A. (2012). Mídia e Crack: Promovendo Saúde ou Reforçando Relações de Dominação? Psicologia: Ciência e Profissão, 32(1), 82-97.

Romanini, M., \& Roso, A. (2013). Midiatização da cultura, criminalização e patologização dos usuários de crack: Discursos e políticas. Temas em Psicologia, 21(2), 483-497.

Roso, A., Romanini, M., Macedo, F. S. de, \& Angonese, M. (2012). O crack nas páginas policiais: "Mais do mesmo" sobre o tema drogas na mídia escrita. In A. C. M. da Silveira, E. M. R. Barichello, F. F. L. Filho, \& M. I. T. Fossá (Eds.). Estratégias midiáticas (pp. 239-254). Santa Maria/RS: FACOS-UFSM.

Roso, A., Romanini, M., Macedo, F. dos S. de, Angonese, M., Monaiar, A. B., \& Bianchini, M. P. (2013). Discourses about crack in the printed mass media. Estudos de Psicologia (Campinas), 30(3), 455-465.

Roso, A. (1997). Grupos focais em psicologia social: Da teoria à prática. Psico, 28(2), 155-169.

Singly, F. de. (2007). Sociologia da família contemporânea. Rio de Janeiro: Editora FGV.

Thompson, J. B. (2007). Ideologia e cultura moderna - Teoria social crítica na era dos meios de comunicação de massa (7a. ed., Grupo de Estudos sobre Ideologia, Comunicação e Representações Sociais - PPGP/PUCRS, Trad.). Petrópolis: Vozes.
Thompson, J. B. (2008). A mídia e a modernidade (10a. ed., W. de O. Brandão, Trad.). Petrópolis: Vozes.

Vedovatto, S. M. A. (2010). Contrapondo o discurso midiático sobre drogas - Nem tão feios, nem tão sujos, nem tão malvados: Pessoas de bem também usam drogas!. In L. M. B. Santos (Ed.), Outras palavras sobre o cuidado de pessoas que usam drogas (pp. 159-166). Porto Alegre: Ideograf/ Conselho Regional de Psicologia do Rio Grande do Sul.

Wurdig, K. K., \& Motta, R. F. (2014). Representações midiáticas da internação compulsória de usuários de drogas. Temas em Psicologia, 22(2), 433-444.

Zanotto, D. F., \& Assis, F. B. (2017). Perfil dos usuários de crack na mídia brasileira: Análise de um jornal e duas revistas de edição nacional. Physis Revista de Saúde Coletiva, 27(3), 771-792.
Recebido: 11/09/2014

$1^{\text {a }}$ decisão editorial: $28 / 03 / 2018$

Aceito: 02/05/2018 